\title{
The Place of Individual Rights in Communal Africa
}

\author{
Samuel Aloysius Ekanem Ph.D \\ Department of Philosophy, University of Calabar, Nigeria
}

\begin{abstract}
This paper has as its objectives the determination of whether or not traditional African societies were truly communalistic and whether individuals' rights were subsumed under the community as so many people claimed. This research which was corroborated by other scholars and supported by the body of maxims that guided traditional African societies reveals that traditional African societies were truly communalistic but does not consume the individual rights. Individual rights and values existed side by side the communal values and only gave way to communal values in cases of a conflict between the two. The paper recommends that communal values should be made the bedrock of our current democracy to quicken it and make it thrive.
\end{abstract}

DOI: $10.7176 / \mathrm{JPCR} / 49-01$

Publication date:June 30th 2020

\section{Introduction}

A careful look at the history of African societies showcases the fact that African societies have always had a consistent administration and governance that is based on communalism. Individuals were seldom seen as separate from the community; for "the state of being of the community determines what becomes the lot of the individuals, irrespective of the values ... cherished by the individual" (Olatunji 102). In communal Africa therefore, the individual finds himself tied up and guided by the values of the community. Menkiti even claims that in communal Africa, "it is the community that defines a person as a person, not the static quality of rationality, will and memory" (172). Asouzu commenting on African communalism asserted, "in communalism people took it for granted that the community has the right of appropriation over the rights or obligations of its members ... it is the community that mostly determines who should live and who should not have life" (351).

Is there a place for individual rights in communal Africa? Would be the question that would develop in an individual mind after careful assimilation of the few remarks that have been made above. This paper attempts an answer to this question.

\section{What is Communalism?}

In the words of Gyekye, "communalism is the doctrine or theory that the community (or group) is the focus of the activities of the individual members of the society" (36). Communalism is a way of life where emphasis is placed on the common good rather than on individual goods. In communalism according to Ephraim, each member of the society has "a common spirit to work together, live together, feel together, and in fact, arbitrate one another" (31). The individuals in the society are expected to be guided in their actions by the communal values which include: mutual aid, caring for others, interdependence, solidarity, reciprocal obligation, social harmony, mutual trust, sharing resources and social responsibility.

From the foregoing, it could be said that communalism has three features:

1. Lays much emphasis on cooperation as the best way to sustain the community.

2. It takes human relations as the most crucial elements of social organisation.

3. There is the belief that the measure of the value of an action, a process or an endeavour, lies in the extent to which it promotes human well-being.

\section{Communalism in Traditional Africa}

There is a general belief among African scholars (especially) that traditional African societies were communalistic in nature (Bisong, Between Communalism and Individualism, 2). Asouzu confirms this when he asserted that, "generally in traditional African society, the community constitutes the point of orientation for almost all human activities and determines human life" (350). Nyerere also alluded to this fact, when he claimed that in traditional African societies individuals were poor or rich, sad or happy, stable or unstable, depending on the situation of the community. Hence, "if a tribe prospered, all the members of the tribe shared its prosperity" (244). Kenyatta commenting on this also stressed that in African thought, "the uniqueness of an individual is a secondary fact about him or her. The primary fact is that he is first and foremost several people's relative and several people's contemporary" (http://africanconsciousnessdotorg.wordpress.com/...s/jomo...).

Other proponents of the doctrine that traditional Africa was basically communalistic include scholars like: Sekou Toure, Edward Blyden, John Mbiti, Kwame Nkrumah, Leopold Senghor, Bolaji Idowu, et cetera. For them any understanding of African person must be from the communalistic perspective.

Apart from the testimonies of these scholars, enumerated above, popular proverbs in Africa also lay credence 
to the fact that traditional Africa was indeed communalistic. For instance the Binis of South Western Nigeria would always proclaim: aghakugbe, uduehiri seaghae (with compromise and cooperation the ant can be properly dissected and its heart shared among people). This means that by imbibing the communal values of cooperation and compromise, even the most difficult task could be accomplished. The Yoruba people also have the following proverbs that highlight the importance placed on communal values:

Enikan ku jeawa de (an individual does not make a forest)

Agbajo owo ni anfi so aya (unity is strength)

Igi kan ko le du ighose (a tree does not make a forest)

Niko owo rim omo eyo ni n fi iku pa won (lack of unity in a community makes it susceptible to danger).

The Boki people of south-south Nigeria would always drum to its children that

Ekrog dibon, eshi ojie ki che ki che (pigs in a herd share one bitter kola)

Oshi ka nchi okpu ka nchi (he who eats alone dies alone)

Bukyu bushuam bunyin (common death is sweet).

The Igbo people never forget their work song ibu anyi danda (no load is insurmountable for the ants). This means that there is no work or difficulty that cannot be overcome through collective effort.

Other popular African maxims showcasing the value attached to communal living by traditional Africans include: The reason two deer walk together is that one has to take the mote from the other's eye.

The poor kinsman does not lack a resting place

Because the tortoise has no clan, he has already made his casket

If all the people were to carry the heavens, on one individual would become humpbacked

The left hand washes the right hand and the right hand washes the left hand

If one person alone scrapes the bark of a tree for use as medicine, the pieces fall on the ground

One finger alone cannot lift a thing

A person is not a palm tree that he should be self-sufficient

Solitariness is a pitiable condition.

These maxims continually remind a typical African that values of collective action, mutual aid, cooperation, interdependence, solidarity, social harmony and mutual trust are necessary not only for the advancement of the society but also for the individual well-being. African traditional society therefore as stated by Nwoko

Is a society where individualism is considered as a taboo, where each member takes the interest of the community as his own. His pride is, community is power. The more united he is to the community, the more he sees the community as a mere extension of the family (30).

Thus, the need to live together in community is seen as part of African existential status. The individual has meaning only in the context of the community.

\section{Individual Rights in Communal Africa}

Individual rights or human right according to Gyekye are "claims that human beings are entitled to make by reason of their being human" (150). These are rights that a person has by reason of the fact that he/she is a human. The rights outlined in the The Universal Declaration of Human Rights (UDHR) include: right to life, freedom from torture, freedom from slavery, right to fair trial, freedom of thought, conscience and religion, freedom of speech. Others include right to food, clothing, housing and medical care, social security, work, equal pay for equal work, right to form trade unions and right to education (Bisong, Human Rights Violation, 10).

Many people are of the view that individual rights are subsumed under the communal values in traditional Africa. It is on this ground that we can understand Mbiti's assertion that "the community must create or produce the individual" (107). According to him, the individual can only exist corporately in traditional life. It is on this basis that Asouzu also asserted that in traditional communal Africa, "the community determines who should live and who should not have life" (351). Mbiti stressed further that "it is only in terms of other people does the individual become conscious of his own being, his own duties, his privileges and responsibilities towards himself and towards other people" (108). This implies that the individual's perception of reality, including his rights, privileges and duties are determined from the point of view of the community. An African according to this view is not seen separately from the community which can be said to violate the general concept of man as an individual who is free and self-determining (Sogolo 191). The implication of this is that, if man cannot exist on his own, but corporately, then he cannot exercise his ability to choose for himself and to formulate his plans - meaning that the concept of individual rights has no place in African traditional society.

Some scholars however think differently, for instance Gyekye asserts thus

Communalism as understood and practiced in the traditional African society does not, on my interpretation, absorb individuality ... communalism is not at variance with the concept of individual right - that is, human rights. It is indeed the exercise of individual rights - which include the right of individual to exercise his or her unique qualities, talents and dispositions that enhance cultural development and ensure the material and political success of the 
community (African Cultural Values 151).

Like Gyekye, Menkiti sees the traditional African as not only a communitarian by nature but also by nature other things which therefore bestow on him freedom and rights. In his words

Besides being a communitarian by nature the human person is, also by nature, other things as well. By other thing, I have in mind such essential attributes of the person like rationality, having a capacity for virtue and for evaluating and making moral judgments and hence, being capable of choice (Person and Community in African Thought 111).

Menkiti's position which is also the position of this paper is fully supported by the body of proverbs or maxims that rules the life of African. These maxims include:

It is by individual efforts that we can struggle for our heads

The person who helps you carry your loads does not develop a hump

The lizard does not eat pepper for the frog to sweat

If you get your bundle ready you will be helped to carry

One does not fan hot food that another may eat

Nobody cracks palm kernel with the teeth for another to eat.

These maxims are proofs that the individual is not subsumed in the community in communal Africa as some people claim. The maxims suggest that he was seen as a free and responsible being whose initiative, hard work, independence and personal responsibility are necessary for fulfilling his needs and reaching his goals. This freedom and responsibility expected of individuals presupposes individual rights in communal Africa. Cases of expression and asserting of these rights abound.

In traditional African societies for instance, individuals were allowed the right to political participation and freedom of expression of opinion on societal matters. "no one, regardless of age, is prevented from fully participating in the deliberation of the councils or public assemblies" (Gyekye, African Cultural Values 153). African traditional councils or public assemblies allows for the expression of all shades of opinions regarding public matters. This shows that traditional African societies were democratic in nature. Everybody had the right to speak, even against the chiefs of the communities. In Boki for instance, a chief or king could be dethroned if public opinion suggests so. And a decision that has the highest individual support is what is taken. The individuals have more power than the monarch, because the monarch only does what majority of the people have agreed upon - he does not take decisions on his own.

In addition to freedom of speech, there was also in existence the right to freedom of religion. The traditional African man was seen as free to worship a god of his choice. That is why in many African societies (Igbo for example) each household had its own god (chi). This liberality as to religion is argued by many scholars to have lubricated the entrance and growth of Christianity and Islam in Africa (Bisong \& Ekanem, Aristotle's Concept of Happiness, 12). The massive followership these religions recorded would not have been possible if the right to freedom of religion was not in existence in Africa. If individuals were not free to worship any kind of God of their choice, there would be sanctions on those who convert to these new religions. Nothing like that was heard of instead, the society encouraged the people to follow the missionaries. In Calabar, Ekpe masquerade was known to move from compound to compound chasing people to church. This shows the extent of liberality that existed in traditional Africa.

There was also in existence, the right to a fair hearing and trial. Gyekye wrote on this, claiming that " the right includes the principle that no one can be punished without proof of wrong-doing" (African Cultural Values 155). Some of the cases were tried at the lineage level which is synonymous to a trial by jury in the western sense - that is, some individuals acquainted with the traditional law and custom are summoned to try a case. The head of the lineage often presides over the case. The cases not able to be resolved at the lineage level would be taken to the council of chiefs, where the trial would be done at the village square. In Boki, both the accuser and the accused would be given a chance to speak before the listeners would make comments or ask questions. The judgement then would be drawn in favour or against the accused depending on the judgement of the chiefs.

Other rights that were recognized and protected were rights to have food, right to use land that belongs to a whole lineage, right to own private property, freedom of movement, et cetera.

It is vivid therefore, that African communal system does not in actual fact absorb the rights of individuals as so many believe. But it should be noted that individual rights were only recognized as long as there do not conflict with the communal values. This is the basis on which one has to understand the infringement on human rights as in human sacrifice, killing of twins, slavery, cannibalism, et cetera, that were prevalent in the olden days. These practices do not in actual fact contradict the fact that individual rights and values were held in high esteem as Nduka pointed out:

Life, among Ibo, was in general, regarded as extremely valuable. That cannibalism, the killing of twins and inter-tribal wars were rampant in the early days of contact between Nigeria and the West does not contradict the above assertion. The fact is that, there were other views about the individual and the society, which form the background of those practices, which appear to us 
now as abhorrent. For instance, the life of a number of one's tribe or clan was considered more valuable than that of an outsider. Again, the lives of all members of a tribe counted far more than that of an individual member of the tribe. Hence, if the birth of twins was an abomination which the gods of the tribe or clan frowned upon, it was necessary to propitiate the gods, either by killing the twins or by sacrificing other human beings to the gods or by performing some other rites (91).

In traditional African societies therefore, the communal demands were seen as stronger and superior to individual claims to freedom and rights. In the event of conflict between the two, the community demand simply outweighs the individual's claim to freedom and rights. The Boki people would say, kichi kibonge ke ju kizinge (one tree cannot kill a forest). This means that when one tree is taken from a forest, it does not make the forest to cease to exist. Thus, if one individual is denied his right for the sake of the rest of the community, it would have only a slight or no effect on the whole community - the community would still stand like the forest.

\section{Conclusion}

This paper points to the fact that, the traditional African societies were basically communalistic in nature but permits and accommodates the individual's values and rights. We see in this arrangement a co-existence of two seemingly opposed concepts - communalism and individual rights. The relationship between the two is like that of a father and son, when there is a conflict of interest between the two, the interest of the son necessarily gives way - the interest of the individuals necessarily give way for that of the community in cases of conflict of interest. The logic behind this towering of the community over and above the individual is to ensure cooperation of all individuals as well as to ensure continuity of the society.

As a result of this communal arrangement, crime was relatively nonexistent in traditional African societies. I remember when I was a little boy, I never saw padlocks on our doors. The doors were always left open and nothing missed. Our foods were cooked and kept in open kitchens with no fear of being stolen or poisoned. Yams would be stacked in unprotected barns and not one would be stolen. On Christmas day, we move round the village, eating anywhere we like without fear of being harmed. Those were the days when everybody slept outside during dry season, without fear of losing his/her head to ritual killers. Those were the days where an errant child could be beaten and corrected by an elder in the village without prior consultation with the parent. This was the era of mutual sharing, mutual help and solidarity.

Now in our contemporary Africa, because communal values no longer outweighs individual values. We see a lot of evils that were not known in time past. Even with our high fences, we are not safe from the activities of armed-robbers, ritual killers and kidnappers. Because individual values and interests now outweigh communal values and interests, we see an individual or group of individuals looting funds that were meant for the whole community (Bisong \& Ekanem, 60). It no longer matters to individuals of this day, whether or not the community survives. What matters to them is their personal survival. It is no longer community is strength but individual is strength. Community is no longer the first but the individual. Most communal values that kept African societies in peace and unity have been replaced by individual values. It is no longer 'we' but 'I'. This is precisely the reason why democracy has failed in Africa. Many people thought that the problem of Africa is their form of government leading to a clamour for a change of government to democracy. Today a lot of African countries have changed to democracy with no noticeable change in the status of the countries (Bisong, Which Way Africa, 36).

As long as the individual values continue to triumph over communal values in Africa, Africa would remain stunted. African nations would never be counted among comity of nations unless traditional communal values stand as the foundation of democracy.

Works Cited

Asouzu, I. Ibuanyidanda: New Complementary Ontology beyond World-Immanetism, Ethnocentric Reduction and Impositions. Zweigniederlassung Zurich: LIT VERLAG GmbH \& Co. KGWien, 2007.

Bisong, P.B \& Ekanem, S.A. The contemporary Nigerian summum bonum and its effect on the economy:, Sophia: African Journal of Philosophy and Public Affairs (Calabar). Vol.15 no.1, 2015, 57-61.

Bisong, P. B. "Which Way Africa: Multiparty or One Party System of Government? A move to fashion a Democracy that is truly African”. Bulletin Social-Economic and Humanitarian Research», № 2, 2018, 36-42.

Bisong, P. B \& Ekanem, S.A. Aristotle's concept of Happiness in the context of Contemporary Nigeria. Flash: Journal of Philosophy and Religion Volume 8, Number 1, 2014, 10-16.

Bisong, P. B. \& Etta. Peter. "Human Rights violation conundrum: Asouzu's Ibuanyidanda Ontology as a Remedy". Advances in Social Sciences Research Journal. Vol.2,No.4, 2014, 9-15.

Bisong, P.B. "Between Communalism and Individualism: Which Way Africa?". RAIS Journal for Social Sciences VOL. 2, No. 2, 2018, 1-10.

Ephraim, I." African Communalism". A Colloquium of African Philosophy. Ed. G.O. Ozumba. Calabar: Pyramid Publishers, 2003. 
Gyekye, K. African Cultural Values: An Introduction. Accra: Sanklfa Publishing Company, 1996.

Gyekye, K. An Essay on African Philosophical Thought: The Akan Conceptual Scheme. Philadelphia: Temple University Press, 1995.

Kenyatta, Jomo. African Consciousness. http://africanconsciousnessdotorg.wordpress.com/...s/jomo... Retrieved January 9, 3014.

Mbiti, J. African Religion and Philosophy. London: Heinemann, 1981.

Menkiti, I. "Person and Community in African Traditional Thought. African Philosophy: An Introduction. ( $3^{\text {rd }}$ edition). Ed. R.A. Wright. Lanham: University Press of America, 1984.

Nduka, O. Western Education and the Nigerian Cultural Background. Ibadan: Oxford University Press, 1964

Nwoko, M.I. The Rationality of Africa Socialism. Roma: University Press, 1985.

Nyerere, J. Ujammaa: “The Basis of African Socialism”. African socialism. Eds W.H. Friedland \& C.G. Resberg. California: Standard University Press, 1964.

Olatunji, O. "The individual-Community Relationship as an issue on Social and Political Philosophy." Issues in African philosophy. Ed. O. Oladipo. Ibadan : Hope Publications Ltd, 2006.

Sogolo, G. Foundation of African Philosophy. Ibadan: Ibadan University Press, 1993. 